\title{
Nasyid as an Islamic Alternative Entertainment
}

\author{
Sholeh Fikri \& Siti Rugayah Hj. Tibek \\ Universiti Kebangsaan Malaysia
}

\begin{abstract}
Nasyidis a musical art which containsIslamic teachingsand lessons from social problems. Nasyid's role is bi-functional, as an entertainment andas a religious and social message.Many other genres of music which can entertain and deliver messages and advicesuch as pop, rock and dangdutbutnasyid is special in its style and 'color'and capable of being an alternative music. This article presents results of a study which used a qualitative methodon data from a survey of 308 respondents, interviews and observations done in the Northern Sumatera Province,Indonesia.Respondents of the survey agreed that nasyid is a viable alternative entertainment. Respondentsreasoned thatnasyid's rhythm is beautiful,its performers are presentably decentand nasyid songs are well-liked by people of all ages.
\end{abstract}

Keywords: Nasyid, entertainment, song, old, young, rivalry

\section{Introduction}

After a long day at work, or reading, or a long deep thinking, doing business, tidying up the rooms and so on, it is normal to feel tired and rest and relaxation are needed to refresh, recuperate or recharge our energy.Sometimes, a good rest can give new ideas and create new vigor and refresh our energy (Liz Mellor 2013:178). It is therefore not uncommon to notice that one's movement is more vibrant and energetic after a good rest, as compared to that before resting.

Life survival is becoming more pressing and it requires man to think and work harderto be able to sustain and compete in the race to achieve his dream. To fulfill the needs of man, a healthy physique and a healthy mind are needed. A healthy body and a healthy mind need entertainment to avoid weariness, boredom and the feeling of tiredness.Meaning, life is not centered at fulfilling the physical needs only but also the nonphysical or spiritual needswhich must be paid a special attention. One of the non-physical needs is the need for entertainment.

Entertainment which is enjoyed almost daily is part of human nature. Al-Qardhawi expounded that Islam is a religion which is in tandem with human nature. Islam does not deprive man of things which are part of his nature such as enjoying a good laugh, rest and relaxation. In fact,Islam encouragesthat which brings joy to life. Islam likes in its adherents optimism and cheerfulness and dislikespessimists, feeling helplessness, and always seeing life as bleak (Yusuf al-Qardhawi 2005:20)

The publication of the book "La Tahzan" by Dr. AidhMohammad Said Al-Qarni is a reflection of theemergence of more and more people who feel sad, difficult and restless in the life they are living. For those who always feel uneasy, life is full of difficulties, troubles and problems. Those who are restless see the world as bleakeven though there is lightand there are many ways to get out of difficulty one is in.

Sadness and difficulty can come at any point in time to the rich or the poor. Difficulties are not only faced by the poor but also the rich. As a means of getting away from the troubles, there are many ways people choose including entertainment. Therefore, entertainment and amusement are part and parcel of a human life.

As translated by MacDonald (1901:251), Imam al-Ghazaliin his bookexplicates the importance of entertainment in life: Or it is said that Music and Singing are sport (lahwun) and play, and so they are, but the whole of this world is sport and play[Qur., xxix, 64]....And all playing with women is sport except tillage, which is the cause of the existence of children. "And all jesting in which there is nothing vile is lawful."That is quoted from the Apostle of God and the Companions(al-Ghazali 1998:381).

Entertainment is very much needed to pacify the heart during difficult times and it can have a calming effect to the chaotic and restless mind. However,entertainment to a Muslim is not the aim but ablessing from Allah The Most Compassionate. Therefore, entertainment must follow the bounds set by Allah,the Creator of the universe (Abu Muawiyah Ismail Kandar 2011:37). Synchronous with the above statement,Imam AlGhazalisaid that "...that sport (lahwun) rests the heart and lightens from it the burden of thinking; and when hearts are overdriven they are blind, and resting strengthens them from serious work. So he, for example, who is persistent in study ought to cease work on Friday, for ceasing work on one day incites alertness on the other days (MacDonald, D.B. 1901:251). Excessiveentertainment or relaxation is forbidden in Islam as it is dangerous, just like it is dangerous to take an overdose of drugs which can detriment one's health. Therefore, relaxation and entertainment in Islam is for the sake of being closer to Allah SWT. The heart of Muslims should not beat except in accordance with what is praiseworthy, and should it be entertained for relaxation for a while, 
it must be done with the aim of getting closer to Allah SWT. According toAl-Ghazali, it is true that this (the matter of relaxation and entertainment)indicates a falling short from the summit of perfection, forthe perfect man is he who has no need that his soul should be rested in other than duty, but "the good deeds of the pious are the evil deeds ofarchangels," and he who mastered the science of dealing with hearts and the different waysof being kind to them to lead them to the Truth,knows absolutely that resting them with such things as these is a useful medicinethat cannot be done without (MacDonald D.B. 1901:252).

Not only rest is needed in matters of working but also in the matters of worship and rituals. The number ofraka'at in prayers (two, three, four or more) has the interval of the tahiyyatseating after every two raka'atswhich is an opportunity to rest in the solat(prayer) ritual. Imagine that a type of solat has 10raka'ats and there is no rest such as seating in tahiyyat after every two raka'ats. Surely, the task of performing the solat is tiring and can become boring. In fact, Al-Ghazali said to the effect of "those who frequently perform solat must rest at certain times as there are times when solat is forbidden and that the rest can help in doing other things,help in refreshing one's vitality as one cannot continuously sustain one's vitality except for theProphets(Al-Ghazali 1998:381).

If someone is asked what can entertain people, surely the answer is thatwhich can bring fun and joy, either in the form of staging of a theatre, comedic writing or performance, singing,watching television, listening to the radio or the likes.Another question arises as to how one is to choose the type of entertainment to fulfill his need. The answer to that, man usually chooses one that is easily available,cheap, easy to get and pleasing.

Firstly, easily available entertainment is that which is easily reachable to the person, such as radio and television. Listening to the radio can be enjoyedwhile doing various activitiessuch asdriving, reading, cookingor relaxing during lying down. Television is different in that itrequires special time and attention as the watcherneeds to physically sit in front of the television to enjoy the programs on television. Therefore, other activities such as driving, reading, and cooking are difficult to do simultaneously with watching television as watching television requires a person to pay a special attention to the television, use his sight and listen with his ears.

Secondly, the entertainment must be cheap and affordable. Radios and televisions are among the cheapest forms of entertainment and relaxation as opposed to other types such asgoing to a concert or going on a holiday. Listening to music on the radio or watching it on televisionis a considerably cheap alternative entertainment as many can afford a radio or television.

It has been determined that the type of entertainment closest and cheapest to people is music on the radio and television. The preferable choiceof music should be one which bringsnot only joy to the audiencebut also but also one which brings knowledge, calmness to the mind and tranquility to the heart. It is therefore left to the wisdom of the people to choose which type of musical entertainment, either one with benefits or one with fun only, as the music of choice.

Determining the type of music which can bring benefit as an entertainment is a matter of necessity nowadays as music can influence our daily life. Furthermore, Sulaiman Noordin reiterated the view of Aristotle which said that various emotions can be induced by melodies and rhythms and music can shape the behavior and character ofcertain individuals (Sulaiman Noordin, 1991:4).

People who make entertainmentfor the sake of fulfilling their desires are not few in numbers,and they can sometimes endanger or become threats to lives. Musicadvocating sexual freedom,Satan-worshipping andlegalization of drugsare common phenomena in these modern days. InHollywood,artists which work with those decadencereceived huge amount of funding and sponsorship while thosewho work to create songs ofpeace, unityand love for socialequality are sidelined and not funded (Ibnuyakoob 2013:10).

InIslam there are a few types of music known to the community namely nasyid, qasidah, pop religiand the likes. Except for pop religi which is influenced by pop music, the types of music mentioned just nowwas spread in parallel with the spread of Islam. The contents of such musicare naturally full of religious teachings aboutsolat, haj, zakat, sadaqahand other religious values. Specific toreligi is the fact that the songs are accompanied by modern musical instruments such as guitar, piano and drumsin absence ofkompangwhich is usually used in nasyidsorqasidah.

In tandem with the advancement of our age, the society at large is less receptive to music which has Islamic influence. However, findings of a survey done in North Sumatera proved otherwise as proven in the results of the survey shown here.

\section{Materials and Method}

The population of North Sumatera is heterogeneous and multiracial. The majority ethnic usually have an influence over the lesser ethnic. The Bataksare the majority ethnic accounting for $51.11 \%$ of the total population (Badan Pusat Statistik Propinsi Sumatera Utara 2011). The Batak ethnic, being the majority, has an influence over the other racessuch as the Malays, Javanese, Minang andthe Acehnese. On another note, theBatak community has a traditional saying which goes to the effect of "if a matter cannot be resolved by crying, then 
sing it"(T.M.Sihombing 1986:128).Therefore, listening to music for the North Sumatera community is something of a must.

Their fondness towards ordinary songs like pop, dangdut, irama Melayuand othersis of different degree compared to their appreciation of nasyids. To know the degree of their fondness towards nasyid songs, the authors conducteda survey on them through questionnaireswith a sample population of 308people scattered all over cities in North Sumatera. The sample consisted of respondents of all ages from children, youths and adults. The survey had a population of different educational background, from the low level education to university graduates.In other words, the survey used a method of random sampling.Results of the survey were analyzed using a computer with the help of the SPSS software.

\section{Findings of Survey}

The authors found that the multiethnic population of North Sumatera gave a variety of response to the questions asked in the survey with regards to nasyid music.

In this sectionrespondents were asked about the existing nasyid music in North Sumatera. The purpose of the questions was to identifywhat of nasyid is liked by the respondent, and what of it is disliked, from the aspects of the rhythm or melody, appearance of nasyid performers,lyrical content or themoves of the performers during their performance. The questionnaires were designed so as to obtain definitive information on the advantages and disadvantages of nasyids for future improvement.

It is understood and expected not all people like nasyids. For those who do like nasyid music, there must be reasons why they like the music and therefore it is appropriate to ask the reasons why they like nasyid music. The same goes with those who do not like nasyid songs. A set of 8 questions were asked in the survey which are listed below.

\section{On the melody of nasyid songs}

Nasyid songs generally have a rhythm identical to that of Arabic songs. As readers might be aware, the emergence of nasyid songs coincided with the arrival of Arab traders to the region. It is therefore not strange to observe that the melody of nasyid is very much identical to the melody of Arab songs.

In a blog by Ahmad Syauqi on the history of Ahmad Baqi, it was explained that Ahmad Baqi deepened his knowledge in tarannum, prior to learning the art of nasyid. ${ }^{1}$ It showed that the rhythm in nasyid has the same tune with the rhythm in the recitation of Al-Quran.

The survey in North Sumatera found that 58 respondentsor $18.8 \%$ strongly agree that they are fond of nasyid melody and rhythm, while 209 orang or $67.9 \%$ agree with that statement. A number of 35 respondentsor $11.4 \%$ of the total respondents were less fond of nasyid tunes and only 6 respondentsor $1.9 \%$ registered their dislike of nasyid rhythm. It is noted that more than half of the respondents like the rhythm of nasyid songs.

Respondentswho liked nasyid rhythms stated their reasons for liking it. Among them were that nasyid rhythms are similar to that of Arabic songs (locally known as irama padang pasir or rhythm of the desert), nasyids are easy listening,beautiful plaintive melody which has a calming effect on the heart. Some respondents suggested the rhythm of nasyid be maintained as it is while others recommended that the tune of nasyid songs be mixed with other type of contemporary music for better acceptance by all walks of the society.

In North Sumatera, the el-Surayya group(a nasyid band or group led by Ahmad Syauqi who is the son of the late Ahmad Baqi)and the nasyid group Nurul Hasanah led by Nur Asiyah Jamil added a keyboard as a musical instrument at each of their shows. At the national level of nasyid competition, there exists a type of nasyid called collaborative nasyidwhich combines the playing ofkompang, rebana, tambourinewithmodern musical instruments such as guitar, violin, accordion, flute and the piano(Lembaga Pembinaan dan Pengembangan Seni Nasyid,LPPSN Sumatera Utara 2010).

\section{On the physical appearance of nasyid groups}

North Sumatran nasyid groups have a specific way of presenting themselves when appearing in front of the audience by wearing uniforms of the same color, shape and design. It can be ascertained that all groups don decent Muslim clothes.Usually, female groups would don kebayaand hijab which are color coordinated.Clothes worn by female nasyid groups are suitably categorized as that of Muslimah (female Muslim). See the pictures of a nasyid male group and the typical attire of female nasyid group.

Apart from the decent attire, nasyid groups do moderate bodily movement while singing the song which is choreographed with the melody of nasyid song. 

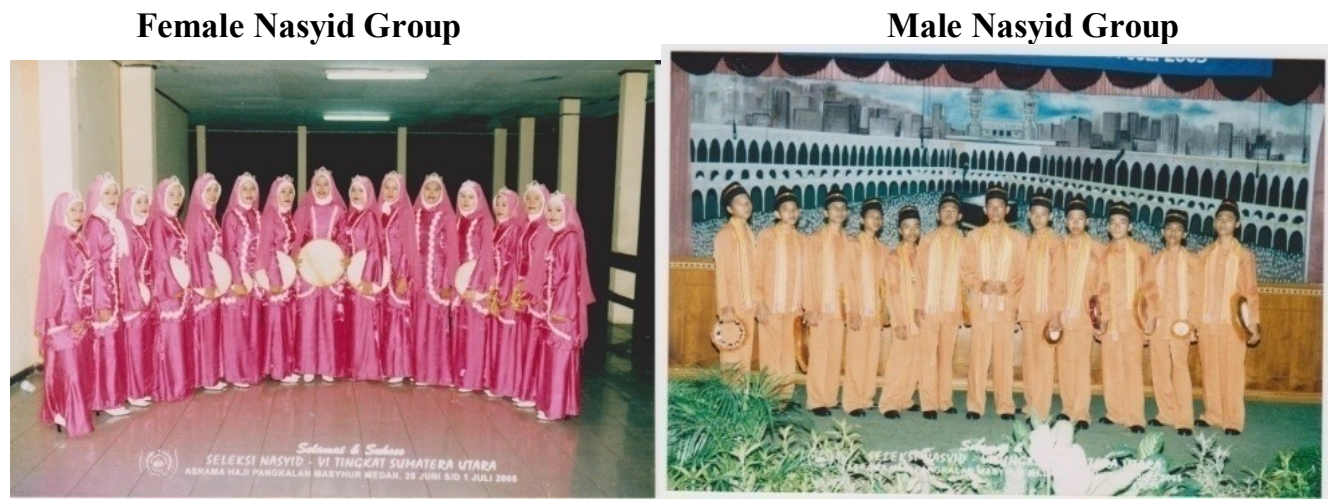

Male nasyid groups also wear some sort of uniforms of the same color and design. Their attires usually look decent and meet requirements of the Islamic shari'ah.Results of the survey proved thatmany of the Muslim community in North Sumateralike the physical appearance of existing nasyid groups. There were 61 respondents or $19.8 \%$ who stated that they like the appearance of nasyid bands very muchwhile some 191 people or $62.0 \%$ said that nasyid groups appeared attractive. Those who were less attracted to nasyid groups' attire were 53 people or $17.2 \%$ and only 3 respondents or $1.0 \%$ found that nasyid groups' uniforms were unattractive. The results were understandable sincethe physical appearance of nasyid groups was generally decent, tidy, beautiful and well-liked by many. This is one characteristic of nasyid groups which must be maintained. The attire donned by nasyid groupsserves as a good example to those who watch their shows, be they children or adults. Children would follow or imitate the fashion of the adults and for adultsthere is a lesson in the example of nasyid attires. The lesson is that a beautiful and modern design such as nasyid group uniforms need not be contradictory to the moral values and traditional customs of the society as well as the religious requirements.

Some respondents agreed with the sense of fashion among nasyid bands while some respondents suggested thatthe attire be made contemporary with current fashion without setting aside Islamic values.

\section{On families' response to nasyids}

The survey was not only an inquiry on the respondent's views but also those of the respondent's family. Answers to that inquiry are as follows:

Those who stated that their family was also fond of nasyid music accounted for 30 people or $9.7 \%$ of total respondents. Those who agreed that their family liked nasyidsamounted to 162 people or $52.6 \%$, while those who less agreed to the statement were 107 people.Some 9respondents or $2.9 \%$ said that their family did not like nasyid songs.

\section{On the respondent liking nasyid songs}

Among the signs that someone loves something is that they can remember or memorize it. One who can memorize a song is said to like the song. In this survey, each respondent was asked how many nasyid songs they can memorize. Respondents who can memorize more than 3 songs were categorized to be those who strongly agree to the statement that they like nasyid songs. Those who agreed to the statement were those who can memorize 2 or 3 nasyid songs andthose who were less agreeable to the statement could memorize probably one only. Respondents who answered they can memorize half of the song or less were considered as did not agree.

It can be seen that 25 people strongly agreed with the statement, a further 75 respondents agreed, while some 135 respondents were less agreeable to the statement. The number of respondents who did not agree was 60.

\section{On the respondent liking the content of the song / lyrics}

Apart from liking the tunes, rhythms and melodies of nasyids, many also found themselves fond of the lyrics. This came about as nasyid lyrics contain words of advice and kind reminders to all. At times,even though the nasyid song was composed a long time ago, the lyrics however stay relevant to current issues. The lyrical content of nasyids is full of meaning, useful as lessons and teachings in life. In this survey, it was found that a large number of respondents like nasyid lyrics.

Respondentswho strongly agreed with that they like nasyid lyrics amounted to 61 people or $19.8 \%$, those who agreed was 213 people or $69.2 \%$, those who less agreeable by stating they like less of nasyid lyrics were 29 people or $9.4 \%$ while 5 respondents or $1.6 \%$ did not like the content of nasyid songs. 
From the results of the survey, it is shown that nasyid lyrics which are generally good and meaningful must be maintained. To address those who did not like the lyrics of nasyids, it is hoped that the content of nasyid songs can be improved and be accommodative to current social issues.

\section{On nasyids being liked by the elderly}

Many consider nasyid less liked by youngstersand more likedby the elders only. This is so because nasyid is deemed identical to the effort of da'wahthat it is less-liked by the youths. Question 6 of this survey was to evaluate whether this statement is true and the following is the result of the survey.

Only $3.6 \%$ of respondents (or 11 only) registered their strong agreement to the statement that nasyid songs are for the old, while $16.6 \%$ or 51 respondents agreed.However, those who agreed less to the statement were 155 respondents or $50.3 \%$ and those who did not agree that nasyids are for the old were 91 people or $29.5 \%$ of the total number of respondents.

The above data show that the statement "nasyid songsare only for the old" is not true.It was proven that nasyids are also liked by younger generation and children.

\section{On nasyids being liked by the youth}

In this questionnaire, it was asked if nasyid is also liked by the youths. 12 people or $3.9 \%$ of respondents answered they strongly agreed that nasyids are liked by the youth and a further 130 respondents or $42.2 \%$ said they agreed with that statement. The amount of respondents who agreed to a lesser degree to the statement was 145 people or $47.1 \%$ while 21 respondents or $6.8 \%$ did not agree. After the numbers were added, the number who at least agreed to the statement was less than the number of respondents who tend not to agree. This means that the youth are less likely to like nasyid song as compared to the old. The result of this question agreed with the previous question which was that nasyids are liked more by adults of old age.

\section{On nasyid being liked by people of all ages}

In the previous question of the survey, it was shownthat nasyidsare more liked by other than the youth. In this section respondents were asked again if nasyids are liked by people of all ages. Those who strongly agreed were 53 people or $17.2 \%$, while respondents who stated their agreement were 159 people or $51.6 \%$.A number of 80 respondents or $26.0 \%$ less agreed to the question while only 16 people or $5.2 \%$ of respondents did not agree that nasyids are liked by people of all ages. This results shows that more respondents were agreeable to the statement that nasyid is for all ages and not limited to certain quarters of the generation.

This survey exposed and concluded thatnasyids can become an alternative form of entertainmentfor Muslim communities in North Sumatera due to some advantages nasyids have over pop, dangdut, rock music etc. Besides, this type of music has its own followers and is well liked societies who are fond of music in general.

\section{Discussion}

An analogy to the state of the nasyid songs is that the art of nasyid is like anuninvited guest in a Muslim home, whereas it should be a part of the home. In the midst of popular culture today, the art of nasyid is considered strange and foreign while some of nasyids are even rendered non-existent.Some Muslims would even find it strange to hear another Muslim chanting a nasyid song even though the fact of the matter is that nasyids are part of the Islamic culture, born out of it and must be liked and preserved by the Muslims (Sholeh Fikri 2012: 120). This is because contents of nasyidscan serve well as an entertainment,containing lessons and advice as well askind reminders to those who listen to them. Indeed, there have been countless debates by the ulema on the permissibility of music. However, considering the fact that the Muslim ummah is living in a multicultural society in the middle of various cultures and their forms, they cannot run away from it and should not isolate themselves or close their doors. Living in isolation and closing own doors would lead to other types of cultures spreading their influence as wide as possible, resulting in their prevalence, as currently happening, while the cultures of the Muslim ummah are left stagnant waiting for its death despite Islam being a religion complete with ritual doctrines and living guidelines. As a consequence, the Muslims themselves follow the path of enjoying other forms of cultures, only seeing those of less value and teachings, shutting their eyes on their very own Islamic cultures which are full of moral values and lessons.

As a proof to that statement, current generations follow the cultures of the West, copying the Western arts of songs, music,and cloth designsdue to the lack of exposure of Islamic cultures. The Islamic culture of performingarts is seldom exhibited, and much less highlighted, leading to people being unaware of its existence and consequently the Muslims look for other forms of entertainment culture. 


\section{Conclusion}

Results from this surveygive enough hope to make the art of nasyida futurealternative entertainmentfor several reasons;its song contents are full of lessons, its rhythm and melody are pleasant to listen to, the physical appearance of the performers isdecent and covers the 'aurat, and that nasyids are well-liked by people of all ages regardless of their gender. However, the quality of nasyids is something which must always be looked after.

\section{References:}

[1]. Abu Muawiyah Ismail Kamdar, 2011. Having Fun The Halal Way Entertainment In Islam, Riyadh: International Islamic Publishing House (IIPH).

[2]. Ahmad Syauqi Ahmad Baqi 2009, Muzik dan Sejarah’s Blog El-Surayya \{http://ahmadbaqielsurayyaindonesia.wordpress.com/\}

[3]. Al-Ghazali, Imam Abu Hamid Muhammad bin Muhammad. 1998. Ihya' 'Ulum al-Din[Revival of Religious Sciences], Vol. II,Cairo: Dar al-Hadits.

[4]. Badan Pusat Statistik Sumatera Utara BPS [The Central Statistics Body, North Sumatera] 2011

[5]. Ibnu yaacob, 2013. Teori Konspirasi Rahsia Yahudi Dalam Filem Hollywood [The Theory of Secrets of the Jews Conspiracy in Hollywood Films], P.Pinang: Es Publisher Sdn.Bhd.

[6]. Liz Mellor, 2013. An investigation of singing, health and well-being as a group process. British Journal of Music Education, 30, pp 177-205 doi: $10.1017 /$ S0265051712000563.

[7]. MacDonald, D.B., 1901. Emotional Religion in Islam as affected by Music and Singing. Being a Translation of a Book of the Ihya' Ulm ad-Din of al-Ghazali with Analysis, Annotation and Appendices. Journal of The Royal Asiatic Society of Great Britain and Ireland, pp. 195-252. \{https://www.ghazali.org/articles/gz-music.pdf \{

[8]. Sholeh Fikri, 2012. (PhD Thesis). Al-Sam $\square \square$ Development, Kajian Seni Nasyid di Sumatera Utara [A study on the art of nasyid in North Sumatera], Bangi: Universiti Kebangsaan Malaysia.

[9]. Sihombing, T.M. 1986. Filsafat Batak, Tentang Kebiasaan-Kebiasaan Adat Istiadat[Batak Philosophy, On the Norms of the Customs and Traditions]. Jakarta: BalaiPustaka.

[10]. Yusuf al-Qardhawi, 2005.Fiqhu al-lahwiwa al-tarwih [Islamic Jurisprudence of Entertainment and Relaxation], Cairo: MaktabahWahbah

[11]. Sulaiman Noordin, 1991. Muzik Rock dan Nilai Moralnya [Rock music and its moral values]. Bangi: Center of General Studies, Universiti Kebangsaan Malaysia.

\section{Authors' Biodata}

Sholeh Fikri (Ph.D.) is apost-doctoral researcher at the Faculty of Islamic Studies, Universiti Kebangsaan Malaysia. He is also a lecturer at Institut Agama Islam Negeri (IAIN) Padangsidimpuan, North Sumatera, Indonesia. Siti Rugayah Hj.Tibek (Ph.D.) is a professorin the Department of Da'wah and Leadership, Faculty of Islamic Studies, Universiti Kebangsaan Malaysia. 